\title{
COMO E PORQUE TERMINOU A MONARQUIA BRASILEIRA $\left(^{\star}\right)$.
}

\author{
ALDO JANOTTI \\ Do Departamento de História da Faculdade de Filo- \\ sofia, Letras e Ciências Humanas da Universidade de
} São Paulo.

Na história da Monarquia brasileira deve-se levar em conta, antes de mais nada, um fato que a caracteriza: referimo-nos tanto à facilidade com que ela surgiu quanto à facilidade com que ela desapareceu.

A Monarquia surgiu em 1822, quando o Brasil proclamou a sua independência em relação a Portugal. Dissemos proclamou e acreditamos tê-lo dito corretamente, pois que essa independência, tal foi a facilidade com que a realizámos, resumiu-se mais numa proclamação do que pròpriamente numa conquista obtida a custas de esforços, de sacrifícios, da guerra enfim. E' preciso observar, inicialmente, que o Brasil separou-se de Portugal, uma metrópole que, como consequiência da sua natural fraqueza, nunca esteve em condições de impedí-lo, explicando-se assim a maneira pacífica pela qual se processou a independência. Contràriamente à América Inglêsa e à América Espanhola, que precisaram enfrentar contra as suas metrópoles não só incerta como também sanguinolenta e longa luta de vida e de morte, a história do Brasil não registra uma guerra de independência. Mas não foi apenas a impotência de Portugal que facilitou a nossa emancipação, como também o comportamento favorável que o rei de Portugal D. João VI e seu filho D. Pedro, tiveram em relação ao Brasil. D. João VI, com tôda certeza interessado na continuação do domínio lusitano, posto que monarca português, paradoxalmente, no entanto, foi obrigado

(*). - Conferência preparada a fim de ser proferida na Universidade de Toulouse. (Nota da Redação). 
a tomar decisões no Brasil, colônia onde de 1808 a 1821 se estabelecera, juntamente com a sua côrte, fugindo à invasão napoleônica de Portugal, que grandemente contribuiram para a nossa independência: pressionado pela Inglaterra, abriu em 1808 os portos brasileiros a tôdas as nações chamadas amigas, concedendo nos liberdade de comércio, e fazendo terminar assim o regime do monopólio, indiscutìvelmente o regime que mais fortemente caracterizava o estatuto colonial do Brasil; elevou o Brasil à categoria de Reino Unido a Portu-. gal, igualando polìticamente a colônia à metrópole; e finalmente, embora pareça incrível, às vésperas da sua volta para Portugal, aconselhou seu filho D. Pedro, que ficava no Brasil na qualidade de principe-regente, a tomar a iniciativa de libertar a colônia da metrópole da qual êle era o seu próprio soberano. D. Pedro, agińdo sobretudo em função dos seus interêsses, proclamou a independência, criando com isso a situação singular de ter o Brasil se libertado de Portugal pelas mãos de um português. Por

\footnotetext{
"uma simples transferência pacífica de poderes da metrópole para o nôvo govêrno brasileiro se fêz a independência" (1) ;
}

e com ela, surgia a Monarquia, verdadeira planta exótica na América e que, na opinião de um nosso historiador, representava

\footnotetext{
"a solução mais viável correspondente ao entendimento entre os interêsses da Inglaterra e os dos grandes proprietários de terras e de escravos" (2).
}

Dessa Monarquia, D. Pedro, o seu maior beneficiário, foi o primeiro imperador. Governou até 1831, quando então, como consequiência de uma revolução - que

\footnotetext{
"foi incontestàvelmente um movimento liberal complicado de ressentimento nativista" (3).
}

- precisou abdicar em favor de seu filho, também Pedro de nome, mas que era menor de idade, pois tinha apenas cinco anos. Inaugura-se com a menoridade do nôvo monarca o período regencial, que durou até 1840: foi um período dos mais conturbados da história do Brasil,

(1). - Caio Prado Jr., Evolução política do Brasil e outros Estudos, São Paulo, 1957, pág. 80.

(2) . - João Cruz Costa, Pequena História da República, Rio de Janeiro, 1968, pág. 6.

(3). - Otávio Tarquínio de Sousa, Três Golpes de Estado, Rio de Janeiro, 1960, pág. 98. 
tal a profusão de levantes e de revoltas tanto na capital do Império quanto nas províncias, evidenciando assim, que apesar dos esforços dos regentes,

"todos homens de qualidades e devotados ao país" (4), a $\operatorname{Re}-$ gência "não parecia a fórmula capaz de assegurar a ordem no vasto Império mal articulado e manter a coesão nacional" (5).

E como a provar a afirmação do excelente historiador da República, José Maria Bello, segundo a qual as

"coisas máximas que realizamos têm sempre um sabor de empirismo, de improvisação, imposta por circunstâncias ocasionais" (6),

os políticos do Império, em grande parte demasiadamente confiantes na eficácia do trono como fator de centralização, resolveram através de um golpe parlamentar, precedido de intensa campanha, declarar institucionalmente maior o imperador que ainda era fisicamente menor. O que nós chamamos de golpe da Maioridade fazia terminar o período regencial e iniciava o reinado de D. Pedro II. Segundo expressão de um político da época, esperava-se que

\footnotetext{
"Sua Majestade o Imperador fôsse o instrumento providencial" (7),
}

aquêle que iria resolver os problemas que a Regência não estivera em condições de resolver.

Em 1889 encerrava-se o reinado de D. Pedro II com o advento da República. E

"a extrema facilidade com que se destruiu, na manhã de 15 de novembro de 1889, a Monarquia brasileira foi, por muito tempo, motivo de controvérsia entre cronistas e historiadores de diversos méritos" (8). "Uma simples passeata militar foi suficiente para arrancar-lhe o último suspiro (9).

Um influente ministro do Govêrno Provisório escrevia, poucos dias depois da instalação do nôvo regime:

\footnotetext{
(4). - Idem, ibidem, pág. 203. 214.

(5). - Idem, Bernardo Pereira de Vasconcelos, Rio de Janeiro, 1960, pág.

(6). - História da República, São Paulo, 1956, pág. 20.

(7). - Teófilo Ottoni, Circular, Rio de Janeiro, 1916, pág. 121.

(8). - Bello, op. cit., pág. 23.

(9). - Caio Prado Jr., op. cit., pág. 94.
} 
"O povo assistiu àquilo bestializado, atônito, surpreso, sem co. nhecer o que significava. Muitos acreditavam estar vendo uma parada" (10).

Entretanto, a facilidade com que a Monarquia chegou ao fim não nos deve levar a acreditar que não houve razões, e razões ponderáveis, para que tal fim se desse. Na realidade, o que houve sim, foi um contraste,

\footnotetext{
"um singular contraste entre os acontecimentos, que são quase irrelevantes, e a profundidade das suas raizes" (11).
}

Compreenderemos melhor êsse contraste, estudando as causas do fim da Monarquia.

E' tradição na historiografia brasileira relacionar uma série de questões quando se pretende explicar o fim da Monarquia, e que foram as seguintes: questão federalista, questão abolicionista, questão republicana, questão militar. Comecemos pela primeira, a questão federalista.

A Monarquia brasileira era um sistema político centralizado. Pràticamente nada se fazia no país sem que antes o centro, a capital do Império, o Imperador, se pronunciasse a respeito. Justamente porque se confundia centralização com unidade nacional é que a idéia federalista, embora existisse e, às vêzes, tivesse oportunidade mesmo de se manifestar, não encontrou, no entanto, ambiente favorável à sua realização. O grande temor dos políticos era que o país se fragmentasse territorialmente e o próprio imperador via no sistema federativo

"um desgoverno geral, que acabaria pela separação" (12).

Todavia, por volta do comêço do último quartel do século passado, a idéia federalista passou a adquirir impressionante desenvolvimento. Influências tanto do federalismo americano, o casso da Argentina e dos Estados Unidos, como e principalmente do federalismo europeu, o caso da Itália, Espanha, França, o certo é que a aspiração federalista

(10). - Apud Cândido Teixeira, A República Brasileira, Rio de Janeiro, 1890, pág. 261 .

(11). - Nelson Werneck Sodré, Formação Histórica do Brasil, São Paulo, 1962, pág. 293.

(12). - Apud Pedro Calmon, O Rei Filósofo, São Paulo, 1939, pág. 402. 
transformou-se numa das grandes preocupações dos políticos e da política do Brasil. E assim como acontecia na Europa, onde o ideal federalista se confundia com o ideal republicano, no Brasil o liberalismo cada vez mais se inconformava com a poderosa fôrça central que dominava as províncias e, ao mesmo tempo e por consequiência, revestia o pensamento descentralizador de um sainete anti-monárquico: Monarquia e Federação começam a ser vistas como duas coisas antagônicas. Eram os políticos, portanto, os primeiros a se desencantar com o Império.

Antes porém, êles se desencantaram com o Imperador. E por que? Porque acabaram se irritando com o "Poder pessoal", considerado por êles como uma deturpação do Poder Moderador, supremo regulador do sistema parlamentar. Ora, o Poder Moderador, por falta de condições, não funcionava no Brasil com a mesma precisão como devia funcionar numa característica monarquia parlamentar, a inglêsa por exemplo. Em primeiro lugar, não existia opinião pública organizada no Brasil: o que existia sim, era

\footnotetext{
"uma opinião informe, difusa, inorgânica, que era a que se formava nos centros universitários, nos clubes políticos, nas sociedades maçônicas e principalmente na Imprensa; esta opinião tinha sempre um caráter artificial, era quase sempre um reflexo americano das agitações européias"; e só "exprimia realmente o pensamento de uma pequena parcela das classes altas do país" (13).
}

Em segundo lugar, também os partidos políticos não tinham uma opinião, como não tinham um programa. Eram

\footnotetext{
"simples agregados de clãs organizados para a exploração em comum das vantagens do poder" (14).
}

Nenhum característico marcante separava um liberal de um conservador, como muito bem salientou Zacarias no Senado em 1870 quando afirmou:

"O conservador no Brasil é necessàriamente liberal, porque a Constituição do Brasil contém instituições santas, liberais; o conservaodr quer manter estas instituiçôes; logo é liberal".

Na realidade, o verdadeiro programa dos partidos era a conquista e, mais do que isso, a conservação do poder, o que nos faz compreender porque as grandes reformas propugnadas pelo Partido Liberal -

(13). - Oliveira Viana, O Ocaso do Império, São Paulo, s/d, pág. 25.

(14). - Idem, ibidem, pág. 26. 
eleição direta, reforma judiciária, leis da emancipação dos escravos foram realizadas pelo Partido Conservador. Este, para

"não abandonar o poder, adiantava-se no caminho das inovações e apropriava-se das idéias pregadas justamente pelos liberais" (15).

E finalmente, em terceiro lugar, as eleições, a grande base sôbre a qual deve se assentar uma monarquia parlamentar digna, não davam nenhum índice seguro da opinião nacional. Porque o povo

\footnotetext{
"nunca teve espírito político nem consciência alguma do papel que estava representando" (16),
}

e sendo assim a vida política o domínio de uma diminuta aristocracia agrária, o processo eleitoral não passava de uma simples ficção constitucional. Além disso, nunca houve condições para eleições livres: campeava a fraude, vencendo sempre o partido que estava no poder, funcionavam mal os aparelhos protetores das liberdades individuais, os mandões locais dominavam absolutamente e êstes, verdadeiros tiranetes regionais, por sua vez, devido ao mecanismo da centralização, estavam na dependência dos chefes de Gabinete. Dessa forma o Govêrno, expressão de um rartido, acabava intervindo no processo eleitoral. Mas intervinha para canhar sempre, o que levou Nabuco de Araujo a formular, irônicamente, a seguinte lei:

"O Poder Moderador pode chamar quem quiser para organizar Ministérios; esta pessoa faz a eleição, por que há de fazê-la; esta eleição faz a maioria". E o "recurso" da dissolução da Câmara, o expediente da "consulta à Nação", se havia transformado numa verdadeira burla, em quem ninguém mais acreditava. Dissolvida a Câmara, já se sabia de antemão - com a certeza certa de uma previsão astronômica - que a nova Câmara vinha inteiramente à feição do nôvo Gabinete. Em julho de 1868 caia o gabinete Zacarias com uma maioria unânimemente liberal. Esta Câmara, Itaboraí, conservador, a dissolveu. A Câmara nova, eleita no mesmo ano, veio unânimemente conservadora. Em 1878 deu-se o contrário; foi o Gabinete conservador que caiu; substituiu-o um Gabinete liberal, o Gabinete Sinimbú: e a Câmara, soberbamente conservadora, dissolvida, voltou soberbamente liberal" (17).

(15). - Idem, ibidem, pág. 28.

(16). - Idem, ibidem, pág. 30.

(17). - Idem, ibidem, pág. 34 . 
Curiosa monarquia parlamentar esta, em que o destino dos partidos ao invés de estar vinculado à opinião do povo, estava vinculada sim à opinião dos Gabinetes .

No entanto, e para completar a montagem do mecanismo, porque era o Imperador quem chamava o político que devia organizar o Gabinete, o destino dos partidos, numa espécie de instância final, dependia inteiramente do monarca. Este, mais do que ninguém convencido da artificialidade que caracterizava o regime representativo brasileiro, e sendo, ao mesmo tempo, um espírito equiânime, imparcial, costumava por em prática o processo do rodízio, chamando ao poder de tempo em tempo, ora o Partido Liberal, ora o Partido Conservador. Numa monarquia parlamentar como a brasileira, eivada de vícios eleitorais como os que acabamos de ver, acreditamos não poder agir D. Pedro II de modo diferente. Como acertadamente acentuou um historiador,

"Ele bem compreendia que o papel do rei constitucional, exercido à maneira inglêsa, seria aqui absolutamente irrepresentável por qualquer soberano que aspirasse o título de justo. Se, quando se operava uma crise ministerial, em vez de formar um gabinete de coloração contrária, como costumava de vez em quando fazer, êle adotasse sistematicamente a fórmula britânica e formasse sempre Gabinetes da mesma coloração da Câmara, seria isto - êle bem o sentia fixar no poder ad eternitatem o partido do Gabinete. Seria o que Saraiva chamava 'a condenação dos adversários ao inferno de Dante' - ao ostracismo permanente e irremissivel" (18).

Mas o costume da rotatividade do poder nem era admitido e nem era compreendido pe'os partidos e a consequiência só poderia ser uma: procurando ser, precisando ser imparcial, aconteceu com D. Pedro II aquilo que costuma acontecer - e a História é pródiga de exemplos - com todo aquêle que pretende adotar uma posição de eqüidistância, isto é, acabou não agradando a ninguém, mas descontentando a todos. Descontentando os que estavam na oposição, porque tinham sido apeados do poder e, logo mais descontentando os que eram apeados, porque estavam no poder. Passava então o monarca a ser objeto de rancorosas recriminações, que se manifestavam numa violência proporcional à dimensão dos interêsses prejudicados. Era assim que o jornal do Partido Conservador, em oposição, perguntava:

"Haverá ainda quem espere alguma coisa de D. Pedro II? Para o monarca brasileiro só há uma virtude: o servilismo! Para os ho-

(18). - Idem, ibidem, pág. 40. 
mens independentes e sinceros - o ostracismo; para os lacaios e ns instrumentos da sua grande política - os títulos e as condecorações!"

Em 1868, com a queda dos liberais, era assim que se manifestava o jornal do Partido Liberal:

" $E$ ' necessário denunciar ao país o govêrno pessoal do Imperador com a mesma coragem com que o faziam os conservadores, há bem poucos dias. O Partido Liberal, tendo caido três vezes na esparrela de aceitar o govêrno e contando contra si três reações violentas, a de 1842,1848 e 1868, deve compreender que já não the é mais possível dirigir os destinos dêste país enquanto durar êste Reinado".

Mais tarde um parlamentar, Ferreira Viana, irá chamar o monarca de príncipe conspirador e usurpador e de César caricato, ameaçando que

"se fôsse mais moço, talvez soubesse lavrar êstes protestos com o próprio sangue, porque a liberdade vale bem êste prêço" (19).

Como muito bem observou Oliveira Viana, autor de $O$ Ocaso do Império, livro que honra a historiografia de qualquer país, o recurso da dissolução da Câmara e da consulta à Nação,

"expediente constitucional tão singelo e normal na Inglaterra, aqui se revestia de um caráter de tirania: era uma sorte de golpe de Estado. Pelo menos, os políticos ameaçados o consideravam tal e ninguém mais do que êles sabia porque" (20).

Era assim que os monarquistas, sucessivamente, atacavam o monarca, cuja pessoa, pela própria Constituição era definida como sendo "inviolável e sagrada". Parece que não compreendiam que, agindo dessa forma, estavam derruindo os alicerces da Monarquia (21). Mesmo porque, complementar a desafeição ao monarca com a desafeição à Monarquia não se carecia de muito.

Com efeito, a partir de 1868, quando os liberais mais uma vez são substituidos pelos conservadores, começa a acentuar-se o movimento em favor da descentralização e da federação e, ao mesmo tempo, acentua-se também o grande processo de desintegração do regime monárquico. Um autor chegou a ver mesmo um sincronismo entre o

(19). - Apud Oliveira Viana, op. cit., pág. 52 .

(20). - Op. cit., págs. 52-53.

(21). - Pandiá Calógeras, Formação Histórica do Brasil, Rio de Janeiro, 1945, pág. 320: 
desenvolvimento do ideal federativo e a queda da Monarquia, pois o liberalismo não hesitará em preferir sacrificar a Monarquia a sacrificar o ideal da federação. E logo mais surgirá o Partido Republicano, cujo grande objetivo, sintomàticamente, será o de realizar a federação.

A outra questão a que esteve ligado o fim da Monarquia foi a abolição da escravatura. Se a idéia federativa trouxe uma espécie de descrença com relação à Monarquia, a abolição teria ocasionado um acentuado sentimento de irritação contra ela. Tão ligada estava a Monarquia à instituição servil que

"foi a lei da Abolição talvez o fator mais eficiente na generalização da idéia republicana" (22).

A questão da emancipação do escravo sempre esteve presente na história da Monarquia brasileira. E' assim que em 1823, José Bonifácio, um dos grandes propugnadores da nossa independência sob a forma monárquica, na sua Representação à Assembléia Geral Constituinte e Legislativa do Império do Brasil sôbre a Escravatura, afirł. mava:

"Nós tiranizamos os escravos e os reduzimos a brutos animais, c êles nos inoculam a sua imoralidade e todos os vícios (...). Sem a abolição total do infame tráfico (...), sem a emancipação sucessiva dos atuais cativos, nunca o Brasil firmará a sua independência nacional, e segurará e dcfenderá a sua liberal constituição" (23).

Todavia, por ser o trabalho escravo a base de economia brasileira e ainda porque com a independência houve a ascenção ao poder e à direção política do Estado da classe dos proprietários rurais, manteve-se a escravidão. Em 1850, em grande parte devido à irritante e insistente pressão da Inglaterra, ficou proibida a entrada de escravos africanos. Esta seria a primeira grande lei da emancipação do trabalho servil, pois fazia secar a fonte da escravidão, isto é, a África. Mas outras leis se seguiram a do tráfico, reflexos de um verdadeiro inconformismo da mentalidade brasileira com o trabalho escravo. A Guerra de Secessão nos Estados Unidos repercutiu intensamente em nossa consciência emancipadora, mormente se considerarmos que a partir de 1870 era o Brasil, juntamente com Cuba, o único país da civilização ocidental onde ainda existia a escravidão. Sabe-se que êste isola-

(22). - Oliveira Viana, op. cit., pág. 69.

(23). - Apud Cruz Costa, op. cit., pág. 13. 
mento teve grande influência sôbre a opinião pública brasileira, principalmente quando começaram a aparecer manifestos internacionais hostis a êstes últimos países que ainda conservavam um regime social universalmente condenado. Será aliás depois de um apêlo feito em 1865 pela Junta Francesa de Emancipação e assinado pelos nomes prestigiosos de Guizot, Laboulaye, príncipe de Broglie, duque de Broglie, Henri Martin e outros, que o Imperador, homem que tinha pretensões literárias e se lisonjeava muito com a amizade e a consideração de intelectuais de renome mundial, mas que até então estava desirteressado pela questão escrava, levará o Ministério a tomar conhecimento oficial dela; e na Fala do Trono de 1867 abordou o assunto, sugerindo, embora de modo muito discreto, que se iniciassem as reformas necessárias (24). A insinuação imperial foi fortemente criticada e muito mal recebida nos círculos políticos de maior influência, mas

\footnotetext{
"partindo de quem partia, a mais alta personalidade do país, e manifestada assim pùblicamente, não podia deixar de frutificar no terreno já tão preparado da opinião pública. O próprio Conselho de Estado, apesar do reacionarismo que o caracterizava, começa a estudar as medidas possíveis a serem adotadas" (25).
}

Em 1871 a chamada Lei Rio Branco estabelecia a liberdade dos nascituros e, completando-a, em 1885 a Lei Saraiva-Cotegipe determinava a libertação dos escravos desde que atingissem a idade de sessenta e cinco anos. Dessa forma, não entrando mais negros da África, não nascendo mais escravos e libertando-se o escravo aos sessenta $\mathrm{e}$ cinco anos, a escravidão no Brasil estava destinada a desaparecer com o tempo. Esta é a que se poderia chamar de primeira fase do movimento abolicionista, ou seja, a abolição gradual, lenta, natural. Um influente político, com muita precisão, resumiu a tendência de se resolver dessa maneira a questão servil, numa fórmula famosa:

"não parar, não retroceder, não precipitar".

Não se parou, nem se retrocedeu, mas se precipitou. Realmente, a partir de 1885 inaugura-se uma nova e definitiva fase do movimento abolicionista, a_da abolição imediata, que adquire,

"como que de súbito, uma aceleração vertiginosa e delirante, que haveria de arrastar consigo, não só os seus opositores mais ferrenhos, como os próprios fundamentos da Monarquia" (26).

(24). - Caio Prado Jr., História Econômica do Brasil, São Paulo, 1956, págs. 181-182.

(25). - Idem, ibidem, pág. 182.

(26). - Oliveira Viana, op. cit., pág. 71. 
Várias razões explicam o porque de se exigir a abolição imediata. Uma delas está relacionada com o comportamento do clero, que se colocou decididamento ao lado da abolição. E o clero, convém salientar, especialmente o alto clero, estava estremecido com a Monarquia. E' que, além das outras questões, houve também uma questão religiosa, muito importante para uns, sem muita significação para outros, mas que contribuiu, muito ou pouco, para o fim da Monarquia. Essa questão religiosa pode ser assim resumida: um excessivo regalismo, herança da monarquia portuguêsa, presidia as relações entre a Igreja e o Estado, regalismo êsse que fazia com que nenhum ato praticado pelo Pontífice ou pela Cúria, por ordem dêle, fôsse exequível no Brasil, sem que tivesse sido confirmado pelo placet do govêrno imperial; intervinha o Estado nas questões da Igreja e o eclesiástico era considerado mero funcionário público, tendo em relação ao Estado os mesmos deveres do funcionário. Esta situação acabou sendo a fonte de vários conflitos, sobretudo aquêle que explodiu em 1873, envolvendo os bispos de Olinda e do Pará de um lado e a maçonaria e o Govêrno do outro. O Govêrno, cujos dirigentes em grande parte eram maçãos, sentiu-se melindrado pelos ataques dos bispos à excessiva influência maçônica nas irmandades religiosas e resolveu processar os bispos. Estes, em 1874, foram condenados a quatro anos de prisão com trabalhos forçados. E' bem verdade que no ano seguinte os bispos foram anistiados, mas a chamada questão religiosa trouxe um resultado negativo para a Monarquia. Esta perde o apôio da Igreja que, ressentida, se desinterêssou da sorte do Império, havendo mesmo quem diga que ela viu a República como uma libertação.

Também o Exército, fôrça

\footnotetext{
"que havia assegurado até então com a sua espada os direitos dos senhores de escravos" (27),
}

aderiu à idéia abolicionista, manifestando ao Govêrno, através de documento famoso, não mais estar disposto a ser desviado da sua missão

"de manter a ordem, tranquilizar a população e garantir a inviolabilidade das famílias" para a "da captura dos pobres negros que fogem à escravidão, ou porque vivam cansados de sofrer-lhes os horrores, ou porque um raio de luz da liberdade lhes tenha aquecido o coração e iluminado a alma".

(27). - Idem, ibidem, pág. 75. 


\section{$-316-$}

E há que se acrescentar ainda a intensa campanha abolicionista desenvolvida por oradores e publicistas notáveis.

Contudo, muito mais importante do que a atitude do Clero, do Exército, dos oradores e dos publicistas e como que dando o verdadeiro sentido da campanha abolicionista, existiu um fator econômico que de forma alguma pode ser esquecido:

\footnotetext{
"o sistema de trabalho escravo já não bastava para atender às novas condições de produção que o desenvolvimento da economia brasileira vinha exigindo. Novos métodos de produção estavam a exigir novas relações de produção" (28).
}

A partir da segunda metade do século passado, assiste-se ao deslocamento do centro econômico dos engenhos do Nordeste para as fazendas do Sul. Em São Paulo, especialmente, com o desenvolvimento da lavoura de café — que, segundo Pierre Monbeig, desdè os seus inícios,

\footnotetext{
"a été un épisode de l'expansion de la civilisation capitaliste éclose sur les deux rives de l'Atlantique" (29),
}

- abrem-se novas perspectivas à técnica do trabalho rural. Os novos fazendeiros, não mais patriarcas senhoriais e sim grandes senhores de terra possuidos de espírito comercial, transformam as lavouras de café em emprêsas industriais, procurando elevar ao máximo a produção do café. Para tanto, necessitavam de mão-de-obra barata e adeqüada. Como o escravo não mais vinha da África e porque o comércio de escravos das províncias do Norte para as do Sul se esgotava, interessaram-se pela imigração. Nas lavouras cafeeiras paulistas o escravo encontrou no imigrante italiano um concorrente vitorioso, pois o traba'ho livre do colono, associado à prosperidade da lavoura, afigurava-se muito mais rendoso. Além disso,

\footnotetext{
"o desenvolvimento, posto que lento, das indústrias fabris e do comércio urbano, abria sensivel brecha na longa hegemonia dos senhores rurais" (30).
}

Em 1888 a idéia abolicionista se realizava completamente quando a princesa-regente Isabel, pois que seu pai, o Imperador, se achava na Europa, assinava a chamada Lei Áurea, que declarava extinta a escravidão no Brasil. Para nós, que estamos preocupados com o fim

(28). - Cruz Costa, op. cit., pág. 15.

(29). - Pionniers et planteurs de São Paulo, Paris, 1952, pág. 93.

(30). - Bello, op. cit., pág. 79. 
da Monarquia brasielira, o que nos interessa são as consequiências da abolição.

19). - A abolição abrupta trouxe

“o baque fragoroso da organização agrícola de várias zonas entre as quais a da província do Rio de Janeiro, que era ainda, por essa época, a mais rica das províncias do Império" (31).

2. $)$. - A Monarquia capitalizou os prejuízos. Os senhores de escravos - ou seja, a aristocracia agrária, a classe rica pròpriamente dita - não se conformaram com a abolição abrupta e muito menos com o fato de não terem sido indenizados; sentiram-se abandonados pela Monarquia e acabaram por abandoná-la, desinteressando-se pela sorte do regime que haviam servido e do qual também se serviram. E, convém notar, a aristocracia que abandonava a Monarquia era a classe verdadeiramente superior do Império,

"superior em experiência, em prudência, em pendores conservantistas, e em conexão com as instituiçōes" (32).

3a) . - A República capitalizou os lucros . A partir da abolição, o pensamento republicano que vinha se desenvolvendo com lentidão e sem vibração, adquiriu celeridade e expandiu-se ràpidamente, transferindo-se o entusiasmo da idéia abolicionista para a idéia republicana (33). Conforme observou Joaquim Nabuco,

"o grosso das forças republicanas vem do descontentamento provocado pela abolição" (34).

Cotegipe, prestigioso chefe conservador, tenazmente tinha se oposto à lei da abolição. Chamou-o a princeza-regente e, mostrandolhe o entusiasmo popular provocado pela referida lei, perguntou-lhe se não fôra acertado votá-la. Profèticamente o famoso político respondeu:

$$
\text { "Vossa alteza redimiu uma raça, mas perdeu seu trono". }
$$

Vejamos agora a questão republicana.

(31). - Vicente Licínio Cardoso, $\dot{A}$ Margem da História da República, Rio de Janeiro, 1924, pág. 327.

(32). - Calógeras, op. cit., pág. 338.

(33). - Oliveira Viana, op. cit., pág. 87.

(34). - Apud Oliveira Viana, op. cit., pág. 110. 
Em 1870 surgia um nôvo partido no ambiente político brasileiro, o Partido Republicano. Muito tempo antes, no entanto, desde a época colonial que as idéias republicanas, de tempo em tempo, aqui ou ali se manifestavam. Sabemos, por exemplo, que em 1794 no Rio de Janeiro era ordenada uma devassa pelo Vice-Rei, Conde de Rezende, contra indivíduos que

"em discursos os mais escandalosos e sacrílegos contra a nossa augusta religião" procuravam justificar a "rebelião da nação francesa" e "destruir a autoridade e o poder dos reis".

Esta devassa ainda fazia referências a muitas pessoas da mesma cidade que,

"esquecidos de si e da honra do nome português que até o presente consistia principalmente no amor e fidelidade aos nossos clementíssimos soberanos, se arrojam, não só em casas particulares mas ainda em lugares públicos dela; com ocasião das atuais alteraçōes da Europa, a altercar questōes sôbre o govêrno público dos Estados, e em que algumas das referidas pessoas têm escandalosamente proferido: que os reis não são necessários; que os homens são livres e podem em todo tempo proclamar a liberdade; que as leis porque hoje se governa a nação francesa são justas e que o mesmo que aquela nação praticou, se devia praticar neste continente" (35).

Ainda nos fins do século XVIII em Minas Gerais e na Baía pretendeu-se organizar governos independentes e republicanos. Idéias republicanas existiam na Revolução de 1817 e na Confederação de 1824 no Nordeste. E nas agitações que caracterizaram o período regencial, algumas inclusive de coloração separatista, voltariam a se manifestar as idéias republicanas. Como a classe média que representava essas idéias era ainda politicamente muito fraca, o republicanismo limitava-se apenas a se manifestar, sem que tivesse, porém, qualquer possibilidade de concretização. Sòmente quando

"a classe dominante, a dos senhores de terra e de escravaria, se enfraquecesse, quando se dividisse, quando; precisamente, perdida a

- propriedade do escravo, da mão-de-obra agrícola, ela perdesse o interêsse pelo regime que sustentara" (36),

é que poderia se dar o advento da República.

(3́5). - Devassa ordenada pelo Vice-Rei, Conde de Rezende, in "Anais da Bibiioteca Nacional", Rio de Janeiro, 1939, LXI, págs. 249-250, apud Cruz Costa, op. cit., págs. 27-28.

(36). - Cruz Costa, op. cit., págs. 29-30. 
Realmente. Em 1870 uma pequena fração, a mais radical e ultra-democrática, se destacava do velho Partido Liberal, organizando o Partido Republicano. Duas razões devem ser consideradas no apa-. recimento dêsse partido. A primeira é uma razão de ordem externa e se liga ao fato de que, no conjunto das nações americanas, tôdas elas repúblicas, o Brasil monárquico aparecia como uma singularidade política. Tem-se dado, talvez até exageradamente, grande importância à singularidade da nossa situação na América. Um liberal monarquista, Nabuco por exemplo, chega mesmo a ver nela a suprema justificação da idéia republicana:

"Ninguém procure justificar a nossa transformação republicana por motivos tirados das condições e conveniências do nosso país, mas simplesmente de estar o Brasil na América. Dêsse modo o observador brasileiro, para ter uma idéia exata da direção que levamos, é obrigado a estudar a marcha do continente, a auscultar o murmúrio, a pulsação continental. Como a própria data do centenário o indica, muito concorreu para o fato de 1889 a influência literária da Revolução Francesa sôbre a imaginação da nossa mocidade, mas não foi menor o arrastamento americano" e, concluindo, ainda dizia que era "crença fatalista de muita gente que seria esforço inteiramente estéril para o resto da razão e do bom senso do país querer lutar contra o imã do Continente, suspenso, ao que parece, no Capitólio de Washington" (37).

No próprio Manifesto Republicano de 1870 surgia claramente a influência americana com esta afirmação categórica:

"Somos da América e queremos ser americanos".

E Quintino Bocaiuva, chefe do Partido Republicano, assim manifestava em maio de 1889 o seu entusiasmo pela repúb'ica norte-americana:

"Em face dêstes grandes Impérios e dêste lado da América, qual é no mundo inteiro, a nação mais forte e poderosa, a mais unida e a mais sólida a mais rica e a mais satisfeita, a mais tranquila no seu trăbalho e a mais segura dos seus futuros destinos? E' a República dos Estados Unidos da América. Só êste contraste com o resto do mundo é já uma conquista, uma superioridade que fascina os espíritos e robustece a convicção geral quanto à excelência das instituições republicanas" (38).

(37). - Balmaceda, pág. 211, apud Oliveira Viana, op. citt., págs. 94-95.

(38). - Apud Oliveira Viana, op. cit., págs. 95-96. 
Os nossos políticos

"geralmente pouco informados dos fatos econômicos, estrangeiros e nacionais" (39),

pareciam atribuir a prosperidade norte americana mais como consequiência quase que sòmente da forma de govêrno - no caso a republicana - e assim, acreditavam-se no bom caminho ao pretender adotá-la no Brasil como a grande solução para os nossos problemas. Evidentemente que assim pensando não tomavam êles consciência de que também República havia nos demais países da América, sem que êsses países conhecessem a prosperidade da república norte-americana e mesmo do Brasil imperial.

Naturalmente, também o ambiente interno foi favorável ao desenvolvimento do republicanismo no Brasil. Com o fracasso do ideal monárquico-parlamentar, surgia o ideal republicano como um sucedâneo daquêle outro, o ideal monárquico, que fracassava. A 3 de dezembro de 1870 aparecia no Rio de Janeiro o jornal $A$ República, que duraria apenas quatro anos, publicando o Manifesto Republicano, assinado por cinqüenta e poucas pessoas pertencentes à classe média, sobretudo intelectuais, e no qual estavam expostos os objetivos do nôvo partido. Costuma-se ver nêste Manifesto um documento pouco audacioso e pouco original. E' claro e preciso apenas no ataque ao Poder Moderador, símbolo do regime monárquico, e na pregação da idéia federativa, temas êstes que, aliás, antes dos republicanos, já vinham sendo ventilados no Parlamento e na imprensa. Não procurava analisar as grandes realidades econômicas e sociais do Brasil. Evitava, por exemplo,

$$
\begin{aligned}
& \text { "o angustioso problema da Abolição, seiva ou essência da mo- } \\
& \text { narquia", }
\end{aligned}
$$

não desejando os seus autores

"comprometer-se com os ricos agricultores do Sul, sem prever que os elementos mais inteligentes da grande lavoura paulista seriam dos primeiros a antecipar-se à escravidão, inaugurando, por própria conta, o livre trabalho do colono estrangeiro" (40).

Enfim, cingindo-se ao programa dos liberais, mais tímidos do que os homens da Regência, os autores do referido Manifesto procuravam corresponder à moderação a que se habituara o país (41).

(39). - Bello, op. cit., pág. 84.

(40). - Idem, ibidem, pág. 42 .

(41). - Idem, ibidem, pág. 42. 
O Manifesto Republicano não encontrou, porém, muita ressonância. Como observou muito bem um historiador da República, o

"Brasil patriarcal e semi-deșerto, pobre -e inculto, das casas grandes e senzalas, onde não se constituira a verdadeira classe média, não podia ter longa sonoridade para a repercușsão das doutrinas políticas" (42).

Aliás, o sentimento republicano não estava generalizado na consciência das elites e, muito menos, na consciência das massas. Estas, incultas na sua quase totalidade, viam as formas de govêrno como abstrações, que transcendiam de muito o a!cance da sua mentalidade rudimentar. E se

\begin{abstract}
"tivessem de crer em alguma instituição, esta seria a Monarquia, ou antes, o Monarca, o Imperador, entidade feita de carne e osso, que êles sabiam estar vivo e presente na Côrte - mandando; e não na República, uma palavra apenas, coisa vaga, abstrata, estranha, inaccessível à sua limitada compreensão" (4⿳亠丷厂犬).
\end{abstract}

As nossas elites, constituidas pela minoria cultivada das capitais e das cidades importantes, do patriciado da riqueza e da -fortuna, dos quadros de direção dos partidos, dos centros universitários e literários, na sua maior parte encaravam com cepticismo, senão com desconfiança, a instituição republicana (44). Joaquim Nabuco e Rui Barbosa eram os dois grandes expoentes dessa minoria. O primeiro era um monarquista convicto e, temendo que se transferisse para o Brasil o caudilhismo que infelicitava as repúblicas da América Espanhola, especialmente do Prata, declarava no parlamento em junho de 1889:

“Há uma razão para não ter chegado ainda a hora da República, e é que ainda não temos povo, e as oligarquias republicanas em tôda a América têm mostrado ser um terrível impedimento à aparição política e social do povo" (45).

O segundo, Rui Barbosa, nunca se declarou francamente repubicano. O que êle colocava em primeiro plano era a sua idéia federativa e, com a sua famosa fórmula Federaçâo com ou sem a Corôa, manifestava-se quanto muito um indiferente com relação à Moharquia, nunca um adversário dela. Rui e Nabuco

(42). - Idem, ibidem, pág. 43.

(43). - Oliveira Viana, op. cit., págs. 106-107.

(44). - Idem, ibidem, pág. 107.

(45). - Apud Oliveira Viana, op. cit., päg. 108. 
"exprimiam perfeitamento o estado do pensamento liberal do país, no periodo imediatamente precursor da queda do velho regime - e que era: ou de simpatia, ou de indiferença pela Monarquia; mas, não, nunca, de crença no regime contrário - no regime republicano" (46).

Com efeito, geográfica e socialmente, era diminuta a expansão do ideal republicano em 1889 quando se deu o fim da Monarquia. A propaganda republicana concentrava-se no Sul, especialmente em São Pau'o, penetrando muito pouco nas províncias do Norte, preocupadas mais com a abo ição da escravatura. Os veículos dessa propaganda jornais e clubes republicanos - além de se concentrarem também no Sul, não tinham condições de popularizar o pretendido nôvo regime. Os jornais republicanos eram poucos e excetuando alguns das cidades do Rio de Janeiro e São Paulo,

"todos os demais tinham um raio de ação insignificante, senão nulo" (47).

E o mesmo se pode dizer dos pequenos clubes que começaram a se constituir desde o Manifesto de 1870, ou mesmo antes: acredita-se que talvez $90 \%$ dêles

"devia representar nódulos de crentes de tipo passivo ou estático, destituidos de qualquer espírito militante ou de qualquer aptidão evangelizadora" (48).

Os adeptos da República eram encontrados mais entre os estudantes, bacharéis novatos e cadetes da Escola Militar. Eram, de uma maneira geral,

\footnotetext{
"Ietrados inexperientes, cheios de entusiasmo juvenil, mas sem grandes responsabilidades sociais e, muito menos, políticas" (49).
}

Eram gente das cidades, representantes de uma classe média ou burguesia que, é preciso salientar, com o desenvolvimento da lavoura cafeeira e do comércio, conheceu sensível melhoria do seu padrão de vida. Os elementos da grande aristocracia rural, embora desgostosos com a Monarquia, não se enfileiravam entre os adeptos da República. E o Brasil da época era extraordinàriamente muito mais uma expressão

(46). - Idcm, ibidem, págs. 110-111.

(47). - Idem, ibidem, pág. 113.

(48). - Idem, ibidem, págs. 115-116.

49). - Idem, ibidem, pág. 116 
rural do que urbana. Dessa forma, não é de estranhar, como que simbolizando a fraqueza do republicanismo, o fato de que em 1884 foram eleitos para a Câmara dos Deputados apenas três republicanos, sendo que na legislatura seguinte apenas um conseguiu se eleger.

Dentre os partidárias da idéia republicana tem-se dado especial atenção aos positivistas. Mas êles eram republicanos à sua originalíssima maneira: concordavam com a superioridade da República como forma de govêrno, porém discordavam em muitos, pontos dos republicanos. Estes eram democratas, e os positivistas suspeitavam das maiorias populares e mesmo das maiorias parlamentares. Faziam o possível para evitar a democracia nos negócios do govêrno, pois queriam uma oligarquia de sábios no comando do Estado. Seu govêrno ideal era a República ditatorial. O que repugnava-lhes na Monarquia era o privilégio dinástico e a hereditariedade de sangue, configurando-se a sua ditadura republicana como uma espécie de monarquia eletiva. E o que os aproximava dos republicanos era o princípio da liberdade civil e a preocupação federativa. Não se deve, porém como se pretendeu durante muito tempo - exagerar a importância do positivismo no advento do regime republicano. O positivismo teve uma irradiação insignificante no Brasil, quer nas massas quer mesmo nas elites, mesmo porque os próprios positivistas mostravam-se incapacitados de fazer a propaganda da sua doutrina. Embora intelectualmente prestigioso, seu número era limitadíssimo, pouco mais de cinqüenta, o que levou um autor a dizer, irônicamente, que se fôssemos reunir todos os partidários de Comte existentes no Brasil a 15 de novembro de 1889 , teríamos a surpreza de verificar que todos êles juntos caberiam muito folgadamente dentro do salão do Clube Militar... (50). A influência que teve o pensamento positivista no advento e na organização do regime republicano deve ser atribuida a um fato puramente acidental: a coincidência de serem dêste credo filosófico alguns dos elementos prestigiosos na organização do nôvo regime. Esta influência do positivismo foi então

$$
\text { "uma influência de crentes - e não do credo em si" (51). }
$$

Sòmente porque, para melhor explicar, o influente positivista Benjamim Constant Botelho de Magalhães gozou de efêmera autoridade no govêrno provisório da República é que inexatamente se acreditou

"haver sido o positivismo o criador da República no Brasil" (52).

(50). - Idem, ibidem, pág. 125.

(51). - Idem, ibidem, pág. 126.

(52): - Cruz Costa, Contribuição à história das idéias no Brasil, Rio de Janeiro, 1956, pág. 242 . 
Vemos assim que o Partido Republicano era um pequeno partido, mormente se comparado com as duas grandes organizações partidárias da Monarquia, o Partido Conservador e o Partido Liberal. Mais um partido regional do que nacional, e só em São Paulo é que possuia uma organização menos rudimentar. $O$ ideal republicano que êle pretendia concretizar não havia conquistado ainda nem as maiorias populares, nem as grandes classes conservadoras e nem também as figuras representativas do país. Enfim, um partido que não tinha o poder de realizar uma grande transformação de caráter político. Como então, nessas condições, explicar a vitória do Partido Republicano? E' chegado o momento de estudarmos a questão militar, a última e a mais importante das grandes questões a que esteve ligado o destino da Monarquia, e da qual habilmente os republicanos conseguiram se aproveitar .

Se o Partido Republicano, expressão política de uma classe média ou burguesa, não estava em condições de proporcionar a queda da Monarquia, não se deve esquecer, porém, de um fato capital da nossa história: a identificação do Exército com a classe média .

"Se é verdade que entre nós a classe média não surge com a estrutura econômica robusta que lhe daria tanta influência no destino de outras sociedades, é certo também que essa deficiência surge compensada pela concentração de fôrça política que lhe seria proporcionada pelo surgimento de um verdadeiro poder nôvo: o poder militar. Foi a partir da Guerra do Paraguai que o Exército ganhou, entre nós, a estabilidade e a coesão internas que dêle fariam, daí por diante, o ponto de maior resistência de nosso organismo político. A monarquia agrária, impregnada de civilismo, não quís ou não soube captar a nova fôrça, para a qual não contribuiram os filhos da aristoc:acia produtora de algodão, açúcar e café. Na classe média é que - Exército vai colher os seus oficiais, alguns vindos de soldados, outros preparados nêsse centro de estudos da classe média, que seria por oposição às faculdades jurídicas da aristocracia, desde 1874, a Escola Militar" (53).

A Monarquia realmente, mais do que não pôde, parece que não quís cultivar a simpatia do Exército. Sob êsse aspecto D. Pedro II

(53). - San Tiago Dantas, Dois Momentos de Rui, Rio de Janeiro, 1951, págs. 17-18. 
talvez seja o caso único de rei que não vinculou a sorte da sua Corôa ou da sua dinastia às classes militares que, mesmo depois da Guerra do Paraguai, não conseguiram elevar-se na hierarquia da sociedade imperial (54). O monarca e os políticos que o rodeavam eram sinceramente anti-militaristas, sendo para êles o primado da ordem civil a condição vital dos governos democráticos (55). Secundária era a posição do Exército, visto pela classe dominante como formado de elementos subalternos. E se porventura alguma preferência se lhe pudesse descobrir, esta seria para a Marinha, arma para a qual de bom grado a aristocracia encaminharia a gente de seu sangue, explicando-se assim o fato de que a propaganda republicana na Marinha não conseguira aprofundar-se e mal atingira a juventude da Escola Naval, enquanto que tivera profunda penetração na Escola Mi'itar (56). Os oficiais do Exército, por sua vez, tinham uma idéia fixa: os polítioos eram os inimigos dos militares. Depois da Guerra do $\mathrm{Pa}-$ raguai, que deu ao Exército consciência da sua fôrça e da sua importância, os políticos começam a cortejar os militares e êstes cada vez mais passam a atuar na vida política. Cada partido procurava ter dentre seus filiados os militares mais importantes. E o que alguns po'íticos temiam que acontecesse e outros gostariam que acontecesse, aconteceu: o envolvimento de proeminentes chefes militares acabou ocasionando o envolvimento das próprias Fôrças Armadas na vida política nacional. O movimento abolicionista, a difusão da doutrina positivista

"haviam induzido os oficiais a atitudes comprometedoras em relação às questões políticas em debate. Eles haviam tomado partido: êstes eram abolicionistas; aquêles liberais; aquêles outros, republicanos - e essas atitudes os levavam a freqüentes atritos com os políticos mais representativos dos partidos contrários: deputados, senadores, ministros. Nêstes atritos o espirito de classe logo se revelava - e a questão pessoal tomava para logo o caráter delicado de uma questão de classe" (57).

Esta é a origem de uma série de incidentes que vão configurar a chamada questão militar e que teve importância tão decisiva na queda da Monarquia. Vista em superfície essa questão não passou de uma sucessão de casos disciplinares registrados nos últimos anos da Monarquia, que colocavam em campos opostos oficiais do Exército e polí-

54). - Bello, op. cit., pág. 78.

(55). - Idem, ibidem, pág. 47.

(56). - Cruz Costa, Pequena História da República, pág. 22.

(57). - Oliveira Viana, op. cit., pág. 146. 
ticos civis (58). Todavia, oficiais que foram punidos - e se consideravam injustamente punidos - por se terem imiscuido em questões de natureza po'ítica, sobretudo as relacionadas com a abolição da escravatura, acabaram contando com a solidariedade dos seus superiores e também e por fim com a solidariedade de tôda a classe militar a que pertenciam. Dentre os militares o que mais se destacou na solidariedade aos seus companheiros, a ponto de se transformar na figura nuclear da questão militar e, justamente por isso, no homem que vai vibrar o golpe de morte na Monarquia, foi o marechal Deodoro da Fonseca. Herói da Guerra do Paraguai, onde adquiriu largo prestígio nas fileiras, era considerado o representante do Exército. Polarizava na sua prestigiosa pessoa a desconfiança, o descontentamento e a irritação dos militares em re'ação aos políticos e ao Govêrno. Isto não significava, porém, que Deodoro fôsse um anti-monarquista. Pelo contrário, era êle sim um anti-republicano: em 1888 recomendava em carta a um de seus sobrinhos

\footnotetext{
"não te metas em questões republicanas, porquanto, república no Brasil e desgraça completa — é a mesma coisa" (59).
}

Assim pensava o homem que um ano depois irá proclamar a República e ser dela o seu primeiro presidente.

Comc explicar essa mudança? Convém inicialmente salientar, que faltou ao Imperador e, sobretudo, aos homens de govêrno, o necessário tato político para evitar ou contornar a questão militar, sua evolução e o seu desfêcho. Vejamos, por exemplo, o comportamento do visconde de Ouro Prêto, último presidente do Ronselho de Ministros da Monarquia, chefe do Govêrno portanto. Era um homem altivo, franco, imperioso e que não sabia transigir. Tomou algumas medidas, sem dúvida alguma condizentes com a firmeza da sua personalidade, mas não condizentes com a delicadeza da situação e da qual êle acabou sendo um fator agravante. Pretendeu reorganizar a antiga milícia civil, a Guarda Nacional, instruí-la e armá-la, a fim de

\footnotetext{
"contrapor ao Exército outro poder, tão eficiente militarmente quanto êle". (60).
}

Mas os militares viram nisso uma provocação. Além disso, parece que chegou a pensar também ęm dividir o Exército, distribuindo os batalhões pelas províncias. Embora Ouro Prêto tivesse desmentido tal intuito, o fato

(58). - Nelson Werneck Sodré, op. cit., pág. 274.

(59). - Apud Ernesto Sena, Deodoro, Rio de Janeiro, 1913, pág. 10.

(60). - Oliveira Viana, op. cit., pág. 171. 


\begin{abstract}
"entretanto, é que todo o Exército estava certo do contrário de que o chefe do Gabinete estava pondo em prática a política da dispersāo, com o intuito de enfraquecê-lo, desarticulando-o na sua poderosa estrutura e afastando-o da sede do Império" (61).
\end{abstract}

E logo mais corria o boato de que Ouro Prêto tinha ordenado a prisão de Deodoro.

Inábil e inoportunamente provocados, os militares passam a exigir a demissão do Ministério Ouro Prêto. Mas êsse movimento contra o Ministério e seu chefe não tinha inicia'mente um intuito republicano. Queria-se apenas uma mudança de gabinete e não uma mudança de regime. Mesmo porque a corrente repub icana no Exército era uma minoria. No entanto, uma minoria ativa, culta e muito sensibilizada pelo positivismo. Eram os cadetes filósofos. Seu chefe, Benjamim Constant Botelho de Magalhães, era um positivista muito culto e brilhante professor da Escola Militar e que tinha grande ascendência sôbre o espírito de Deodoro. A outra corrente - a dos colarinhos de couro -, a mais numerosa, era constituida de oficiais mais antigos, mais graduados, geralmente veteranos da Guerra do Paraguai. Entre os colarinhos de couro

\footnotetext{
"dominava um certo espírito, não diremos de lealdade à Monarquia, mas certamente de respeito e veneraçăo pelo Imperador, que também havia contribuido para a grandeza do triunfo nos campos paraguaios" (62).
}

De uma maneira geral, só podiam admitir a Repúb.ica depois da morte do imperador. Esses dois grupos estavam unidos em tôrno de Deodoro para reagir contra a política anti-militar do Gabinete Ouro Prêto. Mas os cadetes filósofos conseguiram arrastar os colarinhosi de couro para a República, desviando assim contra a Monarquia o movimento que, inicialmente, era dirigido apenas contra o Ministério. Isto se deu a 15 de novembro de 1889 , quando então deixou de existir aquela que foi a primeira e a única Monarquia da história americana.

\title{
III
}

Para terminar, acreditamos necessária uma rápida apreciação de ordem historiográfica. Há tempos que se convencionou atribuir à crise interna das duas últimas décadas do Império como o resultado de uma série de fatôres ou questões — federalismo, abolicionismo,

(61). - Idem, ibidem, pág. 174.

(62). - Idem, ibidem, pág. 195. 
questão religiosa, republicanismo, questão militar - que, atuando em conjunto e num processo cada vez mais dinâmico, acabaram por desfechar na proclamação da República. Como muito bem notou um historiador norte-americano, a historiografia mais recente, conservadora ou liberal, não introduziu novos fatôres à análise convencional. Onde apenas diferem os historiadores, e diferem consideràvelmente, é

"no destaque que dão a um ou mais fatôres, e no grau em que investigam êstes fatôres" (63).

E' assim que Oliveira Viana, republicano desiludido e ardente nacionalista, resumindo o ponto de vista dos historiadores conservadores, acredita que o Império caiu porque estava fraco, não porque $o$ movimento republicano fôsse forte. A República se realizou porque um grupo dentre os republicanos conseguiu induzir o monarquista marechal Deodoro da Fonseca a proclamá-la. Surge então a questão militar para Oliveira Viana como a mais importante de tôdas as questốes. Os historiadores liberais revisionistas - caso de José Maria Bello, por exemplo, - dão ênfase menor ao militarismo. IConcordam em que os brasileiros politicamente conscientes estavam desiludidos com o Império da última década, mas

"a parte desempenhada pelos militares foi decisiva apenas porque a desilusão, o abolicionismo e as tradições republicanas criaram 'condições morais e sociais' para a República" (64).

Já um historiador marxista, Nelson Werneck Sodré, explica o fim da Monarquia como resultado da cisão da classe dominante: segundo êle,

\footnotetext{
"se a classe dominante se apresentasse unida, as reivindicações da classe média não encontrariam ressonância, na época. O Império poderia continuar ainda por algum tempo a ser aquela 'fazenda senhorial modesta e ordenada, mas sem povo', que vinha sendo".
}

Não era o que acontecia, porém. Enquanto uma das frações da classe dominante, aquela que tinha seu poder assentado na cultura da cana-de-açúcar, do algodão e parte da do café, ainda

"permanecia ancorada na estrutura colonial na medida em que perdia em fôrça",

(63). - Stanley J. Stein, A Historiografia no Brasil (1808-1889), in "Revista de História", São Paulo, 1964, n. ${ }^{\circ}$ 59, pág. 121.

(64). - Stein, loc. cit., pág. 122. 
a outra, como era o caso de São Paulo,

"aceitava inovaçōes, abandonava velhas técnicas e normas, alijava o trabalho escravo, esposava relações capitalistas de produção e ansiava por reformas na medida em que ganhava em fôrça".

O Império ainda servia à primeira, que o forjara para assegurar o poder, mas

"já não servia à segunda, que necessitava dominar sem partilha o aparelho do Estado, para colocá-lo inteiramente a seu serviço. As idéais reformistas da época, repudiadas pela primeira, encontravam receptividade na segunda: a abolição do trabalho escravo, a representação eleitoral mais ampla, a renovação de mandatos, a federação, tudo o que, em suma, a República poderia proporcionar" (65).

Acreditamos, no entanto, que a maneira mais històricamente correta de se analisar o fim da Monarquia brasileira não consiste tanto em estudar as diferentes questões bem como o pêso, maior ou menor, que teve cada uma delas no advento da República. Muito mais importante do que a preocupação federativa, o abolicionismo, a questão religiosa, a questão militar, isto é, as questões que desembocaram na República, é o sentido, ou melhor, a raiz profunda de onde elas brotaram a fim de adquirir possibilidade de atuação histórica. Bem meditados os fatos êles nos revelam que o fim da Monarquia é uma história melancólica e, por conseguinte, triste. A Monarquia brasileira sofreu um processo de abandôno, e morreu abandonada. Abandonada pelo grupo político, pela classe clerical, pela aristocracia agrária, pela classe militar. Sob êsse aspecto pode-se dizer que ela não foi derrubada e sim caiu. Caiu porque foi abandonada por aquêles que deveriam sustentá-la. Em 1886, note-se bem a data, mais de três anos antes da instituição do regime republicano, o parlamentar Afonso Celso pronunciava na Câmara dos Deputados estas palavras impressionantemente significativas e proféticas:

"Não há uma classe, um grupo de homens diretamente interessados na manutenção do regime monárquico. Qual a classe mais poderosa e aristocrática do país, à qual cabia por índole e por interêsse manter a instituição? A lavoura? Mas, não há dois anos, vímo-la agredir de um modo descomunal o Imperador e a exorbitância dos seus poderes, porque injustamente o presumia o impulsor do movimento abolicionista do país, movimento que ainda mais

(65). - Formação Histórica do Brasil, pág. 274. 


\begin{abstract}
injustamente supunha lhe ser prejudicial. Isto prova que qualquer agitação mais séria contra a. Monarquia encentrará as adesões gerais ou nenhuma resistência, e triunfará necessàriamente. $O$ orador tem viajado bastante pelo interior do país: ainda não encontrou um monarquista de conviç̧ão, um homem disposto a pegar em armas, e derramar seu sangue para defender o govêrno. Junte-se a êste fato inegável a natural expansão do ideal democrático, que mostra ser uma anomalia absurda a predominância de um trono na América, e concordar-se-á em que se faz mistér ir preparando o espírito público para uma nova forma de govêrno" (66).
\end{abstract}

Estas palavras adquirem maior significação quando sabemos que elas foram pronunciadas num momento em que não só não existia a questão militar, como também ainda não tinha sido abolida a escravid̃̃o. Por conseguinte, antes mesmo da questão militar e da questão abolicionista, consideradas pela historiografia como as duas grandes alavancas do movimento republicano, a Monarquia já estava abandonada. Mas por que foi abandonada? Eis a questão, a verdadeira questão...

Quando se estuda a Monarquia brasileira é impossível deixar de verificar que ela teve uma missão específica na nossa história: a missão de realizar a unidade nacional. Se tomarmos a América Espanhola de um lado e a América Portuguêsa do outro, percebemos claramente que 0 movimento da independência se deu entre as duas regiões seguindo um processo oposto. Na América Espanhola a independência foi um processo divergente, enquanto que na América Portuguêsa foi um processo convergente. Como sabemos, as colônias da América Espanhola estavam agrupadas em quatro grandes blocos unitários, os chamados Vice-Reinos, e quando se tornaram independentes a partir de 1810, êsses blocos se fragmentaram, surgindo dêles mais de duas dezenas de repúblicas, pequenas repúblicas no seu maior número. Portanto, na América Espanhola o caminho percorrido foi o da unidade para a dispersão. No Brasil, país que é quase tão extenso quando a América Espanhola, o caminho percorrido foi justamente o inverso: da dispersão para a unidade. Realmente. $\mathrm{Na}$ época colonial era o Brasil um país disperso, fragmentado em capitanias. Embora a colônia tivesse um centro administrativo, inicialmente a Baía e mais tarde o Rio de Janeiro, as capitanias, tomadas cada uma isoladamente, se comunicavam mais frequientemente com Lisboa do que com a chamada capital da colônia. Cada capitania tinha a sua vida própria, dificilmente se comunicava com as outras capitanis, e como tal con-

(66). - Apud Vicente Licínio Cardoso, op. cit., pág. 324, in nota. 
vergia para o verdadeiro centro, situado além-Atlântico: Portugal. A divisão, a desunião, a divergência enfim, caracterizavam a administração portuguêsa na colônia, ou melhor dizendo, nas colônias. Foi o que constatou o padre Feijo, um dos deputados da delegação paulista às Côrtes de Lisboa em 18:22, poucos meses antes da nossa independência, ao afirmar que

"nós ainda não somos deputados da nação", "não somos deputados do Brasil", "prorque cada província se governa hoje independente" (67).

A consciência da dispersão brasileira, o conhecimento da fragmentação dos blocos unitários da América Espanhola - e sob êsse aspecto foi até uma vantagem a nossa independência ter se dado tardiamente, bem depois das colônias da Espanha - impunham aos políticos responsáveis da época a ter constantemente em mira a unidade do Brasil. E o meio para realizar tal objetivo era a Monarquia, pois êles

"perceberam que a melhor garantia dessa unidade seria fazer do príncipe D. Pedro, no Rio de Janeiro, a grande fôrça centrípeta, o polo de atração das diversas províncias" (68).

Nossa independência em 1822 não foi um fato nacional e sim regional. Regional porque ela se deu efetivamente no Sul, isto é, Minas Gerais, Rio de Janeiro, São Paulo. À Monarquia coube nacionalizar a independência, extendendo-a a tôdas as províncias. Os políticos da Monarquia, apesar das divergências eventuais de interêsses e de posição, sempre tiveram uma preocupação comum: a unidade, e a unidade por intermédio da Monarquia. Também os historiadores brasileiros e mesmo estrangeiros têm dado atenção, e atenção pràticamente revestida da unânimidade, a êste especial papel da Monarquia no Brasil, qual seja o de polarizador da unidade nacional. Varnhagen, por exemplo, escrevia na segunda metade do século passado:

"E, meditando bem sôbre os fatos relatados, não podemos deixar de acreditar que, sem a presença do herdeiro da Corôa, a Independência não houvera ainda talvez nesta época triunfado em tôdas as provincias, e menos ainda se teria levado a cabo êsse movimento, organizando-se uma só nação unida e forte, pela união, desde o Amazonas até o Rio Grande do Sul" (69).

(67). - Diário da Côrte, V, pág. 951, apud Otávio Tarquínio de Sousa, Diogo Antônio Feijó, Rio de Janeiro, 1960, pág. 59.

(68). - Otávio Tarquínio de Sousa, op. cit., pág. 70.

(69). - História da Independência do Brasil, 1957, pág. 259 
Capistrano de Abreu em Caminhos Antigos e Povoamentos também se pronunciava da mesma maneira. O mesmo fazendo Otávio Tarquínio de Sousa na sua alentada obra. E houve até quem pretendesse, certamente não cuidando muito das proporções dos têrmos da comparação, que a Monarquia realizou no Brasil aquilo que os gregos não conseguiram realizar, mesmo porque êles

\footnotetext{
"atingiram a perfeiçã̃o da forma plástica, mas não a atingiram na forma de govêrno, tendo-a apenas esboçado na república imaginária de Platão" (70).
}

E assim por diante.

Todavia, a obra da Monarquia não terminava na realização da unidade nacional. Realizada a unidade, uma outra tarefa se impunha: preservar a unidade. Preservar a unidade do enorme país, verdadeiro continente, que se erigia em gigantesco se se levar em conta a precarieade dos seus meios de comunicação. Trata-se, na realidade, de um aspecto nôvo da mesma preocupação: a Monarquia realizou a unidade, mas agora precisa mantê-la. Ao mesmo tempo, não se compreendia a possibilidade de se manter a unidade sem a Monarquia. Uma coisa necessitava da outra e não era possível uma coisa sem a outra. Monarquia-Unidade é o grande binômio da evolução política brasileira do século passado. Compreende-se assim porque quando em 1831 caiu o primeiro monarca, a Monarquia não caiu. E não caiu, afirma um historiador, devido

"o receio de ver despedaçar-se a bela unidade nacional, alcançada não sem esfôrço" (71).

O período regencial, o da menoridade do segundo imperador, foi o momento em que a. unidade nacional mais foi posta à prova. Nunca, como naquela ocasião, se sentiu tanta necessidade da Monarquia. E consequientemente, nunca o princípio monárquico teve tanto prestígio, a ponto de criar-se

"uma como que mística do trono" (72), considerado êste, "como o grande princípio da unidade nacional e a encarnar a esperança da nação" (73):

(70). - Oliveira Lima, Memórias, estas minhas reminiscências, Rio de Janeiro, 1932, pág. 16.

(71). - Idem, O Império Brasileiro, São Paulo, 1927; pág. 18.

(72). - Otávio Tarquínio de Sousa, Bernardo Pereira de Vasconcelos, pág. 215.

(73). - Idem, Três Golpes de Estado, pág. 139. 
O naturalista francês Saint-Hilaire, contemporâneo dos acontecimentos, percebeu com muita finura essa importância da Monarquia:

"Quant au Brésil", escrevia êle, "ses destinées reposent aujourd'hui sur la tête d'un enfant. C'est un enfant que unit encore les provinces de ce vaste empire; et son existence seule oppose une barrière aux ambitieux qui surgissent de toutes parts avec une égale médiocrité et de prétentions également gigantesques" (74).

Foi justamente por isso, porque os

\footnotetext{
"governos regenciais, orgânicamente fracos, evidenciavam perigos eminentes de desmembramento e de anarquia" e porque ainda "o problema máximo consistia no resguardo da unidade nacional, ameaçada de todos os lados" (75),
}

que se antecipou a maioridade de D. Pedro II em 1840. Os historiadores brasileiros têm dado ênfase ao sentido histórico da Maioridade como um movimento que visava preservar a unidade do Brasil. Joaquim Nabuco, o maior historiador do Segundo Reinado e dos maiores escritores da literatura brasileira, é o nosso escolhido para sintetisar a opinião dêles:

"Se a maioridade não resguardasse a nação como um parapeito, ela ter-se-ia desempenhado no abismo. A unidade nacional, que se rasgara em 1835 pela ponta do Rio Grande do Sul, ter-se-ia feito tôda pedaços" (76).

Inclusive no aspecto externo se manifestava a preocupação com a unidade: a política externa da Monarquia foi movimentadíssima, especificamente na região do Prata, e também tivemos aquilo que no século XIX popularmente se conhecia pela Grande Guerra, a Guerra do Paraguai .

À medida que avançamos na evolução do Império a agitação interna vai perdendo em intensidade (77) e as questões externas vão sendo resolvidas. Conhece o Brasil por fim a paz, a estabilidade, a segurança: a Monarquia realizou e, mais do que isso, preservou a unidade nacional. Mas... com isso, terminou a sua missão. Esgotada

(74). - Voyage dans le District des Diamants et sur le littoral du Brésil, Paris, 1833, II, pág. 402.

(75). - Otávio Tarquínio de Sousa, op. cit., pág. 138.

(76). - Um Estadista do Império, Rio de Janeiro, 1936, I, pág. 32. 80 .

(77). - Caio Prado Jr., Evoluçāo Porítica do Brasil e outros Estudos, pág. 
a seiva que a alimentava a Monarquia acabou se esgotando, perdendo a sua razão de ser. Tanto se dedicou ao problema da unidade que, se não se esqueceu, pelo menos deu muito pouca atenção a outros problemas que agora, reso'vido o da unidade, surgiam como os problemas básicos. Referimo-nos ao desenvolvimento econômico, ao estímulo à emigração, à educação pública, às escolas técnicas, etc.: problemas que a Monarquia não se apresentava em condições de resolvê-los. Daí a Monarquia ter sido abandonada, e daí se explicar a facilidade pela qual ela caiu.

Surgia a República, recebendo como herança os problemas da Monarquia e aos quais vão ser acrescentados os seus próprios problemas. E com ela, a República, nascia uma nova missão, a da integração nacional, em substituição à missão da Monarquia, a da unidade nacional. A consciência de que há vários brasis no Brasil — consciência esta que, acreditamos, surge claramente pela primeira vez no pensamento poderoso de Euclides da Cunha - e que tanto no campo econômico quanto social, político, cultural, êsses diferentes brasis precisam ser integrados num todo uniforme e homogêneo, mas desenvolvido, é a missão da República. Sob êste aspecto a República é que verdadeiramente descobriu o Brasil. Se a Monarquia lutou pela unidade do Brasil e por isso construiu a Pátria Grande a República luta pela integração do Brasil para construir a Grande Pátria. Sem dúvida que é uma tarefa gigantesca, mas nós estamos empenhados nela. 